\title{
Trends in Emissions across the States of Australia 1998-99 to 2007-08: A Shift-share Analysis
}

\author{
Kankesu Jayanthakumaran ${ }^{1}$ and Ying Liu
}

\section{Abstract}

This paper reviews structural changes in emissions of sulphur dioxide (SO2), nitrogen oxide (NOx), carbon monoxide (CO) and particulate matter (PM) in eight Australian states and territories over the period 1998-99 to 2007-08. A shiftshare analysis decomposes the changes of an emission between these two periods into parts ( a national-share component, an industry-mix component and a stateshift component) in order to account for the ecological competitiveness of the states and territories. The results suggest that the changes in state emissions have been substantial, and tend to reflect national, industry and regional policy changes.

\section{Introduction ${ }^{2}$}

In 2001 the Commonwealth government introduced a Mandatory Renewable Energy Target (MRET) to increase electricity generation from renewable energy sources by 9500 gigawatt-hours (GWH) in 2010. To comply with this target, the states introduced various schemes, such as the New South Wales Greenhouse Gas Abatement Scheme (NGAS) of 2003, the Victorian Renewable Energy Target (VRET), the Victorian Energy Efficiency Target (VEET) and the Queensland 13 per cent Gas Scheme (GEC). ${ }^{3}$ At the policy level, procedures are in place to align instruments and coordinate Commonwealth and state legislation, and to ensure that laws meet overall performance and avoid deviations from original targets. But Collins and Whitten (2007) (refer to the Parer Review (COAG 2002)) argue that the states' attempts to tackle MRET have been generally poorly targeted, inconsistent, uncoordinated and costly. They further refer to the Garnaut report (Commonwealth of Australia 2008), arguing that the adoption of an emissionstrading scheme while keeping an MRET scheme in place may increase the overall

$1 \quad$ University of Wollongong; kankesu@uow.edu.au.

2 We do appreciate the comments of the editor, which have greatly improved the paper. Any remaining errors are ours.

3 See Department of Climate Change (2009) for the government initiative regarding climate change. 
cost of climate-change response. The interplay between the states' handling of multiple instruments is crucial to the overall environmental performance of the nation. ${ }^{4}$ Current priced-based instruments used to discourage emissions are complex in their design and implementation, including emissions charges, user charges, product charges, performance bonds, non-compliance fees, subsidies, pollution-discharge fees and deposit-refund schemes, as well as rights-based instruments such as tradable permits and offset schemes. ${ }^{5}$

This paper examines the differences and changes in the levels of sulphur dioxide $\left(\mathrm{SO}_{2}\right)$, nitrogen oxide $\left(\mathrm{NO}_{\mathrm{x}}\right)$, carbon monoxide $(\mathrm{CO})$ and particulate matter $(\mathrm{PM})$ of the eight Australian states and territories (hereafter 'states'). ${ }^{6}$

The National Environment Protection Council (NEPC) provides national standards under the National Environment Protection Measures (Implementation) Act 1998 for air quality, and sets a consistent framework for the monitoring and reporting of $\mathrm{SO}_{2}$ and $\mathrm{NO}_{x}$ emissions, among others. In order to comply, states and territories introduced legislative and regulatory frameworks, such as the Protection of the Environment Operation Act 1997 (NSW), the Environment Protection Act 1994 (Queensland), the National Environment Protection Council Act 1996 (Western Australia), the Environment Protection Amendment Act 2005 (South Australia) and the Environment Protection Act 1997 (Australian Capital Territory) (Department of the Environment and Heritage 2006).

The aim of this paper is twofold: first, to identify the differences in the levels of $\mathrm{SO}_{2}, \mathrm{NO}_{\mathrm{x}^{\prime}} \mathrm{CO}$ and PM in Australian states over the period 1998-99 to 2007-08; and, second, to evaluate these differences using shift-share analysis.

\section{State emissions}

This section uses descriptive analysis to show how state productive structures can explain the gap in emissions between the states and Australia as a whole. The sample comprises eight Australian states and territories during the period 1998-99 to 2007-08. Emissions were converted from kilograms to tons and

\footnotetext{
4 Ancev and Betz (2009) studied the load-based licensing system in NSW (introduced under the Protection of the Environment Operation Act 1997) to reduce nitrogen oxides (NO2) emissions, and conclude that the marginal fee rates were set too low in NSW to achieve a substantial reduction in NO2.

5 While Commonwealth legislation may be in force, states may override it and act in accordance with state laws. States write complementary legislation to support Commonwealth laws. For example, in 1997 the Environment Protection Authority in NSW administered 16 pieces of environment-protection legislation and passed four more.

6 The above pollutants are researchable because, as indicated by Antweiler et al. (2001), they are characterised by: (1) being by-products of goods production, (2) having strong local effects, (3) being subject to regulations, (4) having abatement technologies and (5) having data available.
} 
were reported as the origin of all sources from the NPI (1998-99 to 2007-08). Each state's value-added product was obtained from the Australian Bureau of Statistics (ABS 2007-2008: catalogue no. 5220).

Table 1 indicates the share of total Australian emissions by states from 199899 to $2007-08 .{ }^{7}$ Western Australia (WA) became the largest polluter, with the majority of its emissions (CO was approximately 43 per cent, $\mathrm{NO}_{\mathrm{x}} 34$ per cent and PM 83 per cent) increasing substantially, while Queensland (QLD) became the second ( $\mathrm{NO}_{\mathrm{x}}$ was approximately 24 per cent and PM 5 per cent) in 1998-99. New South Wales (NSW) emitted the highest proportion of $\mathrm{SO}_{2}$, at approximately 42 per cent. In 2007-08, QLD and WA showed the highest proportionate increase in $\mathrm{SO}_{2}$ emissions, at approximately 33 per cent and 22 per cent respectively, while the Australian Capital Territory (ACT), Northern Territory (NT) and Tasmania (TAS) experienced modest declines.

Table 1: Emissions by Australian states (\%), 1998-99 to 2007-08

\begin{tabular}{|c|c|c|c|c|c|c|c|c|}
\hline \multirow[b]{2}{*}{ State } & \multicolumn{4}{|c|}{$\begin{array}{l}\text { Share of total Australian emissions, } \\
1998-99(\%)\end{array}$} & \multicolumn{4}{|c|}{$\begin{array}{l}\text { Share of total Australian emissions, } \\
2007-08(\%)\end{array}$} \\
\hline & $\mathrm{SO}_{2}$ & $\mathrm{CO}$ & $\mathrm{NO}_{x}$ & PM & $\mathrm{SO}_{2}$ & $\mathrm{CO}$ & $\mathrm{NO}_{\mathrm{x}}$ & PM \\
\hline NSW & 41.9 & 18.8 & 18.4 & 4.5 & 22.1 & 26.7 & 22.5 & 10.2 \\
\hline VIC & 15.9 & 14.7 & 13.4 & 2.5 & 16.4 & 13.2 & 17.1 & 2.7 \\
\hline QLD & 19.5 & 13.4 & 24.5 & 5.5 & 32.8 & 13.6 & 24.3 & 19.5 \\
\hline WA & 14.3 & 43.5 & 33.7 & 82.9 & 22.1 & 37.4 & 27.4 & 63.5 \\
\hline SA & 2.9 & 4.8 & 6.2 & 1.3 & 5.5 & 4.5 & 5.3 & 1.9 \\
\hline TAS & 0.7 & 2.6 & 1.1 & 1.1 & 0.5 & 2.8 & 1.1 & 0.8 \\
\hline ACT & 0.1 & 0.8 & 0.8 & 0.1 & 0.1 & 0.6 & 0.5 & 0.1 \\
\hline NT & 4.7 & 1.4 & 1.9 & 2.1 & 2.5 & 1.2 & 2.0 & 1.3 \\
\hline AUS & 100 & 100 & 100 & 100 & 100 & 100 & 100 & 100 \\
\hline
\end{tabular}

Source: NPI: (1998-99 to 2007-08).

Table 2 reports one of the indicators of changes in environmental efficiency as emissions per unit of value-added product. At the state level, these emissions $(\mathrm{kg})$ per gross value-added product provide insights into the efficiency of the productive sectors - information useful for formulating actions to support environmental innovation. Table 2 indicates that emissions per unit of valueadded product varied substantially across the states. The annual change of emissions per value-added product for WA was higher than the national average for $\mathrm{SO}_{2}, \mathrm{CO}, \mathrm{NO}_{\mathrm{x}}$ and PM. The NT showed a lower share of national emissions per unit of value-added product, while having a higher annual average change

7 The data for state-level emissions are available only from 1998-99 (for details, see NPI, 1998-99 to 200708). 
of emissions per value-added product. The annual average change in emissions per unit of value-added product for WA, QLD and $\mathrm{NT}\left(\mathrm{SO}_{2}, \mathrm{CO}\right.$ and $\left.\mathrm{NO}_{\mathrm{x}}\right)$ was higher than the Australian average.

Table 2: Emissions per unit of value-added product, by Australian states, 1998-99 to 2007-08

\begin{tabular}{|c|c|c|c|c|c|c|c|c|}
\hline \multirow[b]{2}{*}{ State } & \multicolumn{4}{|c|}{$\begin{array}{l}\text { Emissions per unit of value-added } \\
\text { product in } 2007-08(\mathrm{~kg})\end{array}$} & \multicolumn{4}{|c|}{$\begin{array}{l}\text { Annual average change of emissions } \\
\text { per unit of value-added product since } \\
1998-99(\%)\end{array}$} \\
\hline & $\mathrm{SO}_{2}$ & $\mathrm{CO}$ & $\mathrm{NO}_{x}$ & PM & $\mathrm{SO}_{2}$ & $\mathrm{CO}$ & $\mathrm{NO}_{x}$ & PM \\
\hline NSW & 0.09 & 0.44 & 0.09 & 0.03 & 12 & 55 & 12 & 03 \\
\hline VIC & 0.09 & 0.28 & 0.09 & 0.01 & 11 & 39 & 12 & 02 \\
\hline QLD & 0.20 & 0.34 & 0.15 & 0.10 & 31 & 54 & 23 & 12 \\
\hline WA & 0.23 & 1.55 & 0.29 & 0.56 & 30 & 228 & 42 & 78 \\
\hline SA & 0.11 & 0.35 & 0.11 & 0.03 & 13 & 48 & 15 & 04 \\
\hline TAS & 0.04 & 0.72 & 0.07 & 0.04 & 06 & 97 & 11 & 05 \\
\hline ACT & 0.00 & 0.09 & 0.02 & 0.00 & 03 & 22 & 05 & 01 \\
\hline NT & 0.22 & 0.44 & 0.18 & 0.09 & 30 & 69 & 24 & 14 \\
\hline AUS & 0.12 & 0.50 & 0.12 & 0.11 & 17 & 71 & 18 & 14 \\
\hline
\end{tabular}

Source: NPI (1998-99 to 2007-08).

One possible explanation for these disparate changes in emissions is the substantial variations observed in increased economic activities in WA, QLD and SA. Exports from these states enjoyed the highest trend growth compared to the mean trend of the nation as a whole. These disparate growth rates resulted in significant changes in the states' shares of exports and trade over the study period. For instance, WA increased its exports from 28.5 per cent to 30.7 per cent, while trade increased from 7.8 per cent to 9.7 per cent. Exports from QLD increased from 19.6 per cent to 20.7 per cent, while trade increased from 6.3 per cent to 8.1 per cent. Exports from the NT contracted, which reduced its share of exports.

The mean value-added growth of every sector of Australia was 6.5 per cent over the study period. QLD, NT and WA enjoyed an above-Australian annual average growth rate of 10.4 per cent, 9.1 per cent and 6.9 per cent respectively, while the other states recorded below the Australian average. The ACT experienced the lowest (positive) growth rate of 3.5 per cent. As expected, growth in valueadded products in WA and QLD reflected as a positive performance in exports and trade, but a negative performance in emissions. 
Table 3: Performance of exports and GDP, 1998-2008

\begin{tabular}{|c|c|c|c|c|c|c|c|c|c|}
\hline & NSW & VIC & QLD & WA & SA & TAS & ACT & NT & AUS \\
\hline $\begin{array}{l}\text { Exports } 1998-2008- \\
\text { trend growth }\end{array}$ & 2.2 & 0.4 & 3.5 & 4.1 & 3.2 & 0.9 & 1.1 & 2.6 & 2. 6 \\
\hline $\begin{array}{l}\text { Value-added } 1998- \\
2008-\text { annual growth } \\
(\%)\end{array}$ & 4.9 & 5.2 & 10.4 & 6.9 & 5.7 & 5.6 & 3.5 & 9.1 & 6.5 \\
\hline \multicolumn{10}{|c|}{ Exports as a percentage of national exports } \\
\hline $1998-99$ & 23.8 & 17.9 & 19.6 & 28.5 & 5.0 & 2.3 & 0.5 & 2.3 & 100 \\
\hline 2007-08 & 23.5 & 15.2 & 20.7 & 30.7 & 5.5 & 1.9 & 0.4 & 2.0 & 100 \\
\hline \multicolumn{10}{|c|}{ Trade as a percentage of GDP $1998-2008$} \\
\hline 1998-99 & 10.9 & 8.6 & 6.3 & 7.8 & 1.7 & 0.5 & 0.2 & 0.6 & 37 \\
\hline 2007-08 & 14.7 & 9.9 & 8.1 & 9.7 & 2.0 & 0.4 & 0.2 & 0.6 & 46 \\
\hline
\end{tabular}

Source: Computed from ABS (2008: catalogue numbers 5220 and 5206)

Environmental regulations have accelerated recently, in order to overcome pressure on the environment, but varying levels of response by federal and state governments are evident at both the policy level and in their implementation. Because the interplay of each state is crucial for the overall environmental performance, we may ask to what extent variations in state emissions are explained by differences in the initial-period national share, industry mix and regional shift. Such variations can effectively be reduced by internalising the externalities. Shift-share analysis captures differences over the initial period.

\section{Shift-share analysis}

The shift-share approach is a method for analysing regional growth by comparing state growth with growth at the national level. While this method can be applied to a range of economic variables (such as employment and trade), the focus of this analysis is changes in emissions over time. Application of the shift-share method to environmental emissions is rare. A few studies have used emissions intensity (Van Rossum and Van de Grift 2009) and emissions levels (Stauvermann 2007) to measure shifts and shares. Emission intensity is obtained by using the ratio of emissions per value-added product to reflect environmental efficiency over time. We chose the level of emissions in terms of $\mathrm{SO}_{2}, \mathrm{NO}_{\mathrm{x}^{\prime}} \mathrm{CO}$ and $\mathrm{PM}$ in our analysis. Despite its limitations, this analysis provided an aggregate measure that captured trends in emissions and their distribution in terms of the national share, the industry mix and regional shift.

This section shows the aggregate change by selected industries in each state's emissions over the study period divided into more meaningful components 
and articulated as a deviation from the national average. Shift-share analysis transposes the source of the change of a particular emission between two periods of time into three parts (the national-share component, an industry-mix component and a regional-shift component) in order to relate regional changes within the nation as a whole. This analysis was expected to capture the magnitude and direction of these three effects for each Australian state. We found that some were environmentally responsible, while others were underperformers relative to the nation as a whole. 'Responsible' states showed a negative net relative change, which indicated lower emissions. The contrary was also true. We transposed each negative and positive change into the national share, the industry mix and the regional shift, following the approach of Stauvermann (2007).

The overall change of emissions, the national share component, the industry component and the regional component can be derived by the manipulation of a series of identities. ${ }^{8}$ The national-share component will show how much of a state's change in emissions can be attributed to the national average. The industry component will show how much of the change of emissions can be attributed to a state's mix of industries. A lower negative value means that a state has specialised in the most efficient industries. A regional component shows changes in emissions as a result of the characteristics of a state. A lower negative value shows the extent to which a specific industry in a state leads in emissions reduction. The components are expected to capture Australian states' ecological competitiveness and, more specifically, all individual industrial sectors' competitiveness in reducing emissions. The negative value reflects environmental efficiency by reducing emissions compared to the previous period.

The emissions data were gleaned from the NPI emission reports (1998-99 to 2007-08). The sample comprised eight Australian states and territories from 1998-99 to 2007-08. Emissions were measured in kilograms, and were reported according to the origin of industries from the NPI emission report (1998-99 to 2007-08). The complete set of data for all eight states was only available for selected industries (such as ANZSIC codes 170, 213 and 261). The data for other ANZSIC codes (such as 114, 151, 181, 201, 202, 203, 211, 281, 118, 70, 80 and 840) were also available for selected states. ${ }^{9}$

8 These identities may be obtained by application to the authors.

9 Selected industries based on the data-available ANZSIC codes: $114=$ fruit and vegetable processing; $151=$ pulp, paper and converted paper-products manufacturing; $170=$ petroleum and coal-product manufacturing; 181 = basic chemical manufacturing; 201 = glass and glass-products manufacturing; $202=$ ceramic-products manufacturing; $211=$ basic ferrous metal manufacturing; 213 = basic non-ferrous metal manufacturing; 261 = electricity generation; $281=$ Water-supply, sewerage and drainage services; $118=$ sugar and confectionery manufacturing; $70=$ oil and gas extraction. 


\section{Results}

Our analysis aimed to demonstrate the relative environmental performance of eight states and territories in relation to the nation as a whole. Due to lack of data, our analysis was restricted to selected industries (Tables 4-7). The overall change figures of -2800 tons and -2500 tons for NSW, the best-performing state in petroleum and coal-product manufacturing (ANZSIC 170) in terms of $\mathrm{SO}_{2}$ and $\mathrm{NO}_{x}$ emissions respectively, indicates that $\mathrm{SO}_{2}$ and $\mathrm{NO}_{x}$ emissions from NSW were, by the end of the period, 2800 tons and 2500 tons lower over the study period. However, this reduction was offset to some extent by the increase of emissions in electricity generation (ANZSIC 261). The electricity-generation sector figures in NSW show that the overall change in $\mathrm{SO}_{2}$ and $\mathrm{NO}_{\mathrm{x}^{\prime}}$ at 40000 tons and 20000 tons respectively, were higher over the study period.

By disaggregating the net relative change of $\mathrm{SO}_{2}$ and ANZSIC 261 into three components, we observed that the industry component was quantitatively the most important regarding relative changes to every state. An industry-mix component showed an increased level of emissions for all states, which tends to indicate that they do not specialise in generating electricity. Alternatively, for $\mathrm{SO}_{2}$ (ANZSIC 261), the state-shift component reduced emissions in WA $(-22,912$ tons), NSW (-67 837 tons) and SA (-10,126 tons), while the national component reduced emissions in every state. The relatively poor overall change in $\mathrm{SO}_{2}$ emissions by VIC (114000 tons) and QLD (60 000 tons) in an industry (such as ANZSIC 261) was due to their relatively heavy reliance on electricity generation (industry component) and the regional shift, which subsequently expanded at a higher rate of emissions than the Australian average.

For $\mathrm{SO}_{2}$ and ANZSIC 213, the overall change for QLD has been reduced considerably (-410 000 tons). The industry component was quantitatively the most important for reducing $\mathrm{SO}_{2}$ for ANZSIC 213 in QLD (-191 498 tons), while the state component (-161 821 tons) and the national component (-56 682 tons) tend to show considerable reductions over time. ${ }^{10}$

\footnotetext{
10 Approximately 40 out of Australia's 200 foundries in Queensland produce 44000 tonnes of castings annually, which is one-third of the national total. This industry has been subject to tight environmental regulations and standards since 1999. (Cleaner Production Manual for the Queensland Foundry Industry: http://www.ecoefficiency.com.au/Portals/56/factsheets/foundry/ecofndry_backgnd.pdf; accessed 18 January 2011).
} 
Agenda, Volume 18, Number 1, 2011

Table 4: Shift-share table for $\mathrm{SO}_{2}$ emissions for the period 1998-99 to 2007-08 (tons)

\begin{tabular}{|c|c|c|c|c|}
\hline $1998-99$ to $2007-08$ & $\begin{array}{l}\text { National } \\
\text { component }\end{array}$ & $\begin{array}{l}\text { Industry } \\
\text { component }\end{array}$ & $\begin{array}{l}\text { State-shift } \\
\text { component }\end{array}$ & $\begin{array}{l}\text { Overall } \\
\text { change }\end{array}$ \\
\hline \multicolumn{5}{|c|}{$170-$ Petroleum and coal products } \\
\hline NSW & -5837 & 500 & -2717 & -2800 \\
\hline VIC & -4837 & 414 & 369 & 300 \\
\hline WA & -167 & 143 & 2324 & 2300 \\
\hline SA & -37 & 31 & -435 & -440 \\
\hline \multicolumn{5}{|c|}{261 - Electricity generation } \\
\hline NSW & -19172 & 127009 & -67837 & 40000 \\
\hline VIC & -4668 & 30924 & 87744 & 114000 \\
\hline QLD & -8336 & 55221 & 13114 & 60000 \\
\hline WA & -4251 & 28163 & -22912 & 1000 \\
\hline SA & -1000 & 6627 & -10126 & -4500 \\
\hline \multicolumn{5}{|c|}{213 - Basic non-ferrous metal } \\
\hline NSW & -1167 & -3943 & 4110 & -1000 \\
\hline VIC & -917 & -3098 & 4015 & 0 \\
\hline QLD & -56682 & -191498 & -161821 & -410000 \\
\hline WA & -14170 & -47874 & 102045 & 40000 \\
\hline SA & -4001 & -13517 & 34519 & -4500 \\
\hline \multicolumn{5}{|l|}{$80-$ Metal ore mining } \\
\hline WA & -2334 & 4101 & 1233 & 3000 \\
\hline SA & -217 & 381 & 90 & -1500 \\
\hline \multicolumn{5}{|l|}{181 - Basic chemical } \\
\hline NSW & -77 & 3913 & -3756 & 80 \\
\hline QLD & -150 & 7655 & 3695 & 11200 \\
\hline \multicolumn{5}{|c|}{211 - Basic ferrous metal } \\
\hline NSW & -533 & 3946 & -512 & 2900 \\
\hline SA & -70 & 518 & 512 & 960 \\
\hline
\end{tabular}

Note: See footnote 8 for the industries for which data were available.

Source: Computed from NPI (1998-99 to 2007-08)

For $\mathrm{NO}_{\mathrm{x}}$ (Table 4), WA showed reductions in emissions in electricity generation (-13000 tons). In this regard, WA was the best-performing state relative to the national average. For $\mathrm{NO}_{\mathrm{x}^{\prime}}$ VIC (53 000 tons), QLD (20 000 tons) and NSW (20 000 tons) were relatively lower environmental performers in electricity generation. For $\mathrm{NO}_{\mathrm{x}}$ and ANZSIC 261, we disaggregated the overall change into three components and observed that the national share and a state-shift component were quantitatively the most important for relative changes for all states. The state-shift component reduced emissions (negative lower value) in every state except VIC. An industry-mix component showed increased emissions for all states, which indicates that they do not specialise in generating electricity. 
Table 5: Shift-share table for NOx emissions for the period 1998-99 to 2007-08 (tons)

\begin{tabular}{|c|c|c|c|c|}
\hline $1998-99$ to $2007-08$ & $\begin{array}{l}\text { National } \\
\text { component }\end{array}$ & $\begin{array}{l}\text { Industry } \\
\text { component }\end{array}$ & $\begin{array}{l}\text { State-shift } \\
\text { component }\end{array}$ & $\begin{array}{l}\text { Overall } \\
\text { change }\end{array}$ \\
\hline \multicolumn{5}{|c|}{$170-$ Petroleum and coal products } \\
\hline NSW & 467 & -1596 & -1371 & -2500 \\
\hline VIC & 262 & -894 & 1832 & 1200 \\
\hline SA & 157 & -536 & -461 & -840 \\
\hline \multicolumn{5}{|c|}{261 - Electricity generation } \\
\hline NSW & 26177 & 761 & -6938 & 20000 \\
\hline VIC & 7853 & 228 & 44919 & 53000 \\
\hline QLD & 28047 & 815 & 8862 & 20000 \\
\hline WA & 8788 & 255 & -22044 & -13000 \\
\hline SA & 3552 & 103 & -5656 & 2000 \\
\hline NT & 1197 & 35 & -1131 & 100 \\
\hline \multicolumn{5}{|l|}{$\begin{array}{l}213-\text { Basic non-ferrous } \\
\text { metal }\end{array}$} \\
\hline QLD & 2618 & -1503 & -114 & 1000 \\
\hline WA & 1683 & -966 & -716 & 0 \\
\hline NT & 374 & -215 & 641 & 800 \\
\hline \multicolumn{5}{|l|}{$80-$ Metal ore mining } \\
\hline WA & 6357 & 6571 & -4928 & 8000 \\
\hline NT & 991 & 1024 & -1415 & 600 \\
\hline \multicolumn{5}{|c|}{$\begin{array}{l}203-\text { Cement, lime, plaster and concrete } \\
\text { products }\end{array}$} \\
\hline NSW & 804 & -896 & 1492 & 1400 \\
\hline VIC & 673 & -751 & -3523 & -3600 \\
\hline WA & 767 & -855 & 688 & 600 \\
\hline SA & 823 & 917 & 495 & 400 \\
\hline \multicolumn{5}{|c|}{211 - Basic ferrous metal } \\
\hline NSW & 1384 & -314 & -470 & 600 \\
\hline SA & 337 & -76 & 40 & 300 \\
\hline \multicolumn{5}{|c|}{$70-$ Oil and gas extraction } \\
\hline VIC & 729 & 125 & 845 & 1700 \\
\hline QLD & 1197 & 206 & 798 & 2200 \\
\hline WA & 1870 & 322 & 809 & 3000 \\
\hline SA & 2057 & 354 & -2410 & 0 \\
\hline NT & 206 & 35 & -41 & 200 \\
\hline
\end{tabular}

Note: See footnote 8 for the industries for which data were available.

Source: Computed from NPI (1998-99 to 2007-08) 
Agenda, Volume 18, Number 1, 2011

Table 6: Shift-share table for CO emissions from 1998-99 to 2007-08 (tons)

\begin{tabular}{|c|c|c|c|c|}
\hline $1998-99$ to $2007-08$ & $\begin{array}{l}\text { National } \\
\text { component }\end{array}$ & $\begin{array}{l}\text { Industry } \\
\text { component }\end{array}$ & $\begin{array}{l}\text { State-shift } \\
\text { component }\end{array}$ & $\begin{array}{l}\text { Overall } \\
\text { change }\end{array}$ \\
\hline \multicolumn{5}{|c|}{$170-$ Petroleum and coal products } \\
\hline VIC & 1255 & -2680 & 1526 & 100 \\
\hline QLD & 10980 & -23455 & -1526 & -14000 \\
\hline \multicolumn{5}{|c|}{261 - Electricity generation } \\
\hline NSW & 5176 & 5595 & -7871 & 2900 \\
\hline VIC & 7843 & 8477 & 16680 & 33000 \\
\hline QLD & 3451 & 3730 & -589 & 6600 \\
\hline WA & 2980 & 3221 & -4202 & 2000 \\
\hline SA & 863 & 932 & -1395 & 400 \\
\hline NT & 1490 & 1611 & -3201 & -100 \\
\hline \multicolumn{5}{|c|}{213 - Basic non-ferrous metal } \\
\hline NSW & 69019 & $\square 61829$ & $\square 43190$ & $\square 36000$ \\
\hline VIC & 34510 & -30914 & 4405 & 8000 \\
\hline QLD & 18823 & -16862 & 55039 & 57000 \\
\hline WA & 4392 & -3935 & -1558 & -1100 \\
\hline SA & 42363 & -37940 & -30412 & -26000 \\
\hline NT & 227 & -204 & 396 & 420 \\
\hline \multicolumn{5}{|l|}{$80-$ Metal ore mining } \\
\hline WA & 9412 & 13602 & -9014 & 14000 \\
\hline NT & 1176 & 1700 & -2377 & 500 \\
\hline \multicolumn{5}{|c|}{211 - Basic ferrous metal } \\
\hline NSW & 149019 & 122466 & 78516 & 350000 \\
\hline VIC & 1020 & 838 & -3158 & -1300 \\
\hline SA & 35294 & 29005 & -65299 & -1000 \\
\hline \multicolumn{5}{|c|}{$70-$ Oil and gas extraction } \\
\hline VIC & 2353 & -1435 & -1318 & -400 \\
\hline WA & 2274 & -1387 & 2213 & 3100 \\
\hline SA & 1804 & -1100 & -504 & 200 \\
\hline NT & 236 & -143 & -392 & -300 \\
\hline
\end{tabular}

Note: See footnote 8 for the industries for which data were available.

Source: computed from NPI (1998-99 to 2007-08).

The overall change figures of -36 000 tons, -26000 tons and -1100 tons for NSW, SA and WA, respectively, made these the best-performing states in basic nonferrous metals (ANZSIC 213) for CO emissions, which indicates that by the end of the period CO emissions were 36000 tons, 26000 tons and 1100 tons lower 
at the national level over the study period (Table 6). An industry component showed a reduced level of emissions for all states, which tends to indicate that they specialise in the basic non-ferrous metal industry. The relatively poor performance in CO emissions by QLD (57 000 tons) and VIC (8 000 tons) in an industry (such as ANZSIC 213) was due to their response to the national-share component and a state-shift component that subsequently expanded emissions at a higher rate than the national average. The relatively poor performance in emissions of NSW in the basic ferrous metal industry (ANZSIC 211) was mainly due to that state's heavy reliance on national and industry components.

Table 7: Shift-share table for PM emissions for the period 1998-99 to 2007-08 (tons)

\begin{tabular}{|c|c|c|c|c|}
\hline $1998-99$ to $2007-08$ & $\begin{array}{l}\text { National } \\
\text { component }\end{array}$ & $\begin{array}{l}\text { Industry } \\
\text { component }\end{array}$ & $\begin{array}{l}\text { State-shift } \\
\text { component }\end{array}$ & $\begin{array}{l}\text { Overall } \\
\text { change }\end{array}$ \\
\hline \multicolumn{5}{|c|}{261 - Electricity generation } \\
\hline NSW & 28545 & -5061 & 3816 & 1600 \\
\hline VIC & 4596 & -8175 & 2579 & -1000 \\
\hline QLD & 7113 & -12652 & -161 & -5700 \\
\hline WA & 9849 & -17518 & -6230 & -13900 \\
\hline SA & 487 & -866 & 589 & 210 \\
\hline \multicolumn{5}{|c|}{213 - Basic non-ferrous metal } \\
\hline QLD & 3447 & -2645 & -202 & 600 \\
\hline WA & 1149 & -882 & 433 & 700 \\
\hline NT & 301 & -231 & -230 & -160 \\
\hline \multicolumn{5}{|l|}{$80-$ Metal ore mining } \\
\hline QLD & 6566 & 6890 & 14544 & 28000 \\
\hline WA & 54715 & 57421 & -22136 & 90000 \\
\hline SA & 2407 & 2527 & -34 & 4900 \\
\hline NT & 3283 & 3445 & -4928 & 1800 \\
\hline \multicolumn{5}{|c|}{211 - Basic ferrous metal } \\
\hline NSW & 2243 & -4509 & -1835 & -4100 \\
\hline SA & 1641 & -3299 & 1858 & 200 \\
\hline
\end{tabular}

Note: See footnote 8 for the industries for which data were available.

Source: Computed from NPI (1998-99 to 2007-08)

For CO, VIC increased emissions in electricity generation (33 000 tons) relative to the national average. By disaggregating the net relative change of CO (ANZSIC 261) into three components, we observed that the state-shift component was quantitatively the most important for the relative changes. On the other hand, a state-shift component effect for CO (ANZSIC 261) tends to show reduced emissions in every state other than VIC, while the national-share effect and industry-mix effects increased emissions in all states. 
The overall change figures of -13900 tons, -5700 tons and -1000 tons for WA, QLD and VIC, respectively, were the best environmental performers in electricity generation (ANZSIC 261) in terms of PM emissions, which indicates that by the end of the period PM emissions were 13900 tons, 5700 tons and 1000 tons lower than the national average emissions over the study period (Table 7). The relatively poor performance for emissions of PM (ANZSIC 261) by NSW (1600 tons) and SA (210 tons) in an industry (such as ANZSIC 261) was due to their response to a national component that subsequently expanded emissions at a higher rate than the national average. An industry component showed a reduced level of emissions for all states, which tends to indicate that they specialise in the electricity-generation industry. The relatively poor performance in emissions by every state in an industry (such as metal ore mining - ANZSIC 80) was due to their heavy reliance on that industry and a national-share shift that subsequently expanded a higher rate of emissions than the national average. For ANZSIC 80, WA indicated an increased level of PM emissions (90 000 tons) relative to other states due to an increase in national (54 715 tons) and industry components (57 421 tons), while a reduction occurred in the state-shift component (-22 136 tons).

\section{Conclusions}

Substantial divergence in emissions $\left(\mathrm{SO}_{2}, \mathrm{CO}, \mathrm{NO}_{\mathrm{x}}\right.$ and $\left.\mathrm{PM}\right)$ and emission intensity (emissions per value-added product) among the states relative to the nation as a whole were evident over the study period. WA, QLD and the NT were identified as growing disproportionately in emissions, and therefore as being relatively lower environmentally efficient states. Measuring emissions per value-added product provides insights into the efficiency of the productive sectors and is useful for formulating actions to support future environmental policies. In this sense, WA, QLD and the NT need to bring their environmental efficiency into line with the other states.

Our findings on shift-share analysis indicate that the states diverged disproportionately from the national average in our selected emissions $\left(\mathrm{SO}_{2}\right.$, $\mathrm{CO}, \mathrm{NO}_{\mathrm{x}}$ and PM) over the study period 1998-99 to 2007-08. On the basis of decomposition, we found that all three components - a national share, an industry mix and a state shift - strongly influenced the divergence from the national average. The extent of the influence varied across industries. For example, notable overall reductions in $\mathrm{SO}_{2}$ emissions occurred in the basic non-ferrous metal industry in QLD - mainly as a result of both industry and state components. Thus, the main conclusion of this paper is that differences in 
national share, industry mix and a state shift together explain the differences in our selected emissions over the study period. The information is useful for formulating actions to support environmental innovation.

We acknowledge the limitations of analysing (a) a selected, small number of industries (rather than entire industries) due to a lack of emissions data at the state level and (b) emissions rather than emissions per value-added product, due to a lack of the necessary data for the corresponding industries. However, the results from our sample industries unambiguously reveal that the changes in state emissions were substantial, and are, to some extent, due to state-specific characteristics that impact on state emissions. One possible explanation for this is that the market-based instruments used to tackle the problem were not appropriately directed, designed or implemented.

Myriad policy instruments have their consequences. Single quantitative instruments may minimise regional divergence of emissions and help the nation reach its intended goals, but the potential role of the above factors in explaining disparities in emissions is the subject of ongoing research. It is only suggestive at this stage.

\section{References}

Ancev, T. and Betz, R. 2009, 'Load-based licensing: getting the rates right', working paper, at: http://www.business.curtin.edu.au/files/Ancev_Betz. pdf; accessed 24 September 2010.

Antweiler, W., Copeland, B. R. and Taylor, M. S. 2001, 'Is Free Trade Good for the Environment?' The American Economic Review 91(4): 877-908.

Australian Bureau of Statistics 2007-08, Australian National Accounts, at: http://www.abs.gov.au/AUSSTATS/abs@.nsf/DetailsPage/5220.0200708?OpenDocument; accessed 27 November 2009.

Collins, D. and Whitten, S. 2007, Use of Market-Based Instruments by Catchment Management Authorities in NSW to Achieve Landscape Scale Change, report to the NSW CMA Chair's Council: NSW.

Commonwealth of Australia 2008, Garnaut Climate Change Review, draft report, June.

Commonwealth of Australia 2002, Energy Market Review: Towards a Truly National and Efficient Energy Market, Final Report, at: http://www.ret.gov.au/ Documents/mce/_documents/FinalReport20December200220050602124631. pdf; accessed 31 January 2011. 
Department of Climate Change 2009, A-Z of Government Initiatives, Canberra.

Department of the Environment and Heritage 2005-2006, Department of the Environment and Heritage Annual Report: Canberra.

NPI (1998-99 to 2007-08), at http://www.epi.gov.au.data/index.html; accessed 28 November 2009.

Stauvermann, P. J. 2007, 'The Regionalized nAMEA-type Matrix (RAMEA/ Regionalized National Accounting Matrix including Environmental Accounts): Methodology, Application and Interpretation: A Dutch Pilot Study', at: http://www.arpa.emr.it/cms3/documenti/ramea/2007_ Stauvermann_RAMEA_Dutch.pdf; accessed 6 October 2009.

Van Rossum, M. and Van de Grift, M. 2009, 'Regional analysis: differences in emission-intensity due to differences in economic structure or environmental efficiency?' Journal of Sustainable Development 2(3): 43-55.

Whitten, S., van Bueren, M. and Collins, D. 2003, 'An Overview of MarketBased Instruments and Environmental Policy in Australia', presented at the AARES Symposium. 